\title{
Makna Hidup Dibalik Seni Tradisional: Studi Fenomenologi Kebermaknaan Hidup Seniman Sunda
}

\author{
Rezza Pahruroji Priatama ${ }^{1}$, Anwar Supenawinata ${ }^{2}$, Ila Nurlaila Hidayat ${ }^{3}$ \\ ${ }^{1,2,3}$ UIN Sunan Gunung Djati, Jl. A. H. Nasution No.105 Cibiru-Bandung \\ 1 e-mail: pahruroji_rezza@yahoo.com
}

\begin{tabular}{|c|c|}
\hline Abstract / Abstrak & Keywords / Kata kunci \\
\hline $\begin{array}{l}\text { Globalization brings positive and negative impacts to the culture, including in } \\
\text { Indonesia. One of the negative impacts is the decreasing interests of Indonesians } \\
\text { on traditional arts, which may lead to less interests on career as an artist. } \\
\text { However, artists in Sanggar Bandungmooi were different. The purpose of this } \\
\text { study is to explore the meaning of life of local artists in Sanggar Bandungmooi. } \\
\text { The method used is qualitative with phenomenology type. The data was collected } \\
\text { using observation and interview. The subjects were two artists, aged } 24 \text { and } 50 \\
\text { years old. The results show that both subjects have a meaning of life that is } \\
\text { beneficial to others. Their meaning of life can help them to determine their life } \\
\text { purposes. Both subjects find the meaning of life through their own efforts and the } \\
\text { supports from the social environment. They try to anticipate negative } \\
\text { consequences and show positive attitudes in facing life conditions. }\end{array}$ & $\begin{array}{l}\text { Meaning of life } \\
\text { Sundanese artists } \\
\text { Traditional art }\end{array}$ \\
\hline $\begin{array}{l}\text { Seiring dengan globalisasi, minat masyarakat terhadap kesenian } \\
\text { tradisional cenderung menurun sehingga turut memengaruhi pula minat } \\
\text { untuk berprofesi menjadi seniman tradisional itu sendiri. Namun } \\
\text { berbanding terbalik dengan seniman Sanggar Bandungmooi. Penelitian } \\
\text { ini bertujuan memperoleh gambaran kebermaknaan hidup seniman Sunda. } \\
\text { Metode penelitian menggunakan pendekatan kualitatif dengan jenis } \\
\text { fenomenologi. Teknik pengumpulan data melalui observasi dan } \\
\text { wawancara. Subjek terdiri dari dua orang seniman Sanggar } \\
\text { Bandungmooi. Hasil penelitian menunjukkan kedua subjek memiliki } \\
\text { makna hidup yaitu bermanfaat bagi diri sendiri maupun orang lain, } \\
\text { sedangkan salah satu subjek memiliki makna hidup lainnya yaitu nyaman } \\
\text { dan senang dalam menjalani sesuatu hal. Makna hidup tersebut diperoleh } \\
\text { melalui upaya sendiri maupun hasil memanfaatkan dan memperoleh } \\
\text { dukungan dari lingkungan sosial. Keduanya tetap memegang teguh dan } \\
\text { terikat dengan makna hidup tersebut dalam menjalankan profesinya, } \\
\text { meskipun merasakan konsekuensi negatif, namun hal itu berupaya diatasi. } \\
\text { Selain itu mereka juga menunjukkan perubahan yang lebih positif dalam } \\
\text { menyikapi kondisi hidup. }\end{array}$ & $\begin{array}{l}\text { Kebermaknaan hidup } \\
\text { Seniman Sunda } \\
\text { Seni tradisional }\end{array}$ \\
\hline
\end{tabular}

\section{Pendahuluan}

Dampak globalisasi sangat terasa terhadap kesenian, karena bangsa Indonesia lebih meminati kesenian dan kebudayaan asing daripada kebudayaan dan kesenian tradisional (Suneki, 2012). Permasalahan yang ada di Indonesia adalah rendahnya kesadaran masyarakat akan budaya nasional terutama seni, didukung dengan hasil penelitian yang menggambarkan minat remaja terhadap kesenian tidak terlalu tinggi dengan presentase $37.5 \%$ (Purnamasari, Suntoro, \& Nurmalisa, 2013). Globalisasi dapat menimbulkan berbagai masalah dalam bidang kebudayaan seperti hilangnya budaya asli suatu daerah dan terkikisnya rasa cinta budaya dan nasionalisme generasi muda (Agustin, 2011). Sejalan dengan beberapa pernyataan tersebut, Hapsoro (2015) juga menyatakan keresahan para seniman dengan kondisi 
budaya saat ini adalah bahwa masyarakat Indonesia, khususnya anak muda sudah melupakan budaya asli Indonesia.

Berkaitan dengan beberapa dampak globalisasi sebagaimana disajikan di atas, dapat dipahami bahwa globalisasi membawa dampak positif maupun negatif bagi kebudayaan khususnya kesenian tradisional di Indonesia. Dampak positif yang dirasakan diantaranya kebudayaan Indonesia termasuk di dalamnya kesenian tradisional menjadi lebih dikenal di berbagai negara lain. Sedangkan dampak negatifnya adalah berkurangnya minat masyarakat Indonesia terhadap kesenian tradisional, hal ini mengakibatkan berkurang pula minat masyarakat untuk berprofesi menjadi seniman. Terkait dengan pilihan sebuah profesi, setiap profesi di dunia memiliki konsekuensi tersendiri (Charlys \& Kurniati, 2007). Demikian pula pelaku seni atau seniman yang mempunyai konsekuensi berbeda dibandingkan profesi lainnya. Profesi dalam dunia seni terbagi menjadi beberapa bidang salah satunya ialah pelaku seni peran yang mengekspresikan karyanya melalui pagelaran teater, pertunjukan drama, serta kabaret. Unsur utama dalam khasanah teater dewasa ini adalah naskah lakon, sutradara, pemain, dan penonton (Santosa, dkk., 2008). Tanpa keempat unsur tersebut pertunjukan teater tidak bisa diwujudkan. Dengan kata lain unsur dari teater dibagi menjadi dua, unsur intrinsik dan unsur ekstrinsik. Unsur intrinsik yakni unsur yang terlibat langsung dalam proses pembuatan karya mereka. Yang termasuk ke dalam unsur intrinsik merupakan pelaku seni peran asli. Artinya mereka adalah orang-orang yang terlibat langsung dalam proses pembuatan karya pertunjukan, mereka juga merupakan orang-orang yang hidup dalam lingkup seni pertunjukan. Sejatinya pelaku seni peran yang baik berorientasi terhadap karya yang dihasilkan. Pencapaian mereka bukanlah materi atau apa yang didapatkan melainkan apa yang telah mereka pertunjukkan terhadap penonton.

Senada dengan profesi lainnya, pelaku seni peran lokal memiliki konsekuensi dalam menjalankan profesinya. Berdasarkan hasil wawancara awal terhadap dua orang seniman Sanggar Bandungmoii, diperoleh keterangan bahwa konsekuensi itu terdapat pada aspek ekonomi dan sosial, kedua aspek itu menjadi masalah utama bagi para pelaku seni peran lokal. Konsekuensi pada aspek ekonomi disebabkan karena loyalitas pelaku seni peran lokal terhadap dunia yang dicintainya. Dalam berkarya pelaku seni peran lokal tidak terlalu mementingkan materi yang didapat melainkan kepuasan dengan totalitas dalam berkarya. Ditambah lagi dengan mereka tidak mempunyai keinginan meninggalkan dunia seni. Mereka lebih banyak menghabiskan waktu untuk dunia seni pertunjukan walaupun dengan konsekuensi yang mereka hadapi khususnya konsekuensi dalam aspek ekonomi, daripada mencari pekerjaan tambahan untuk memenuhi kebutuhan hidup sehari-harinya.

Konsekuensi pada aspek sosial disebabkan juga oleh loyalitas mereka terhadap dunia seni pertunjukan. Banyaknya menghabiskan waktu dalam dunia seni pertunjukan, menyebabkan mereka kurang memiliki waktu untuk hal lainnya seperti waktu untuk bersosialisasi dengan lingkungan keluarga dan tetangga. Selain itu berkaitan juga dengan gaya hidup mereka sebagai seniman. Contohnya penampilan, orientasi hidup dan gaya bicara yang khas dari seniman membuat mereka berbeda dengan kehidupan individu lainnya. Mayoritas individu dengan profesi lain pada era globalisasi ini bersaing dalam 
pemenuhan kebutuhan materi, karena pada dasarnya di zaman serba praktis ini sulit untuk hidup dengan kurangnya kebutuhan materi.

Pada dasarnya manusia cenderung akan mengalami penderitaan dalam menjalankan kehidupannya jika ada kebutuhan yang tidak terpenuhi. Hal ini tentu akan berdampak secara langsung pada kehidupan manusia. Meski begitu ada juga yang berhasil mengatasi kesulitan tersebut bahkan hingga menimbulkan perasaan menyenangkan, hal ini disebabkan karena manusia mampu mengubah penghayatan hidupnya dari tidak bermakna menjadi bermakna. Maka, penghayatan hidup untuk mencari kebermaknaan sangat dibutuhkan bagi kehidupan manusia, karena pada dasarnya pencarian hidup bermakna yang unik merupakan motif utama yang melekat pada diri manusia (Sumanto, 2006; h.119). Makna hidup menurut Frankl adalah proses penemuan yang bermakna intrinsik dan individual (Sumanto, 2006). Definisi lain dikemukakan oleh Bastaman (2007) bahwa makna hidup adalah hal-hal yang dianggap sangat penting dan berharga serta memberikan nilai khusus bagi seseorang sehingga layak untuk dijadikan tujuan hidup.

Wawancara pendahuluan dilakukan pada dua orang seniman anggota Sanggar Bandungmooi. Sanggar tersebut berdiri sejak tahun 1996 dan bertempat di wilayah Bandung sebagai sebuah wadah bagi para pelaku seni peran. Sanggar Bandungmooi masih aktif dalam menggelar pementasan tradisional seperti kesenian longser, badawang dan helaran. Keputusan yang diambil oleh kedua subjek untuk menjalani profesi sebagai seniman dapat dinilai cukup unik karena pada zaman globalisasi saat ini sudah mulai sulit dijumpai generasi muda yang masih memiliki rasa cinta terhadap kesenian dan kebudayaan khususnya seni tradisional Sunda sebagaimana yang dilakukan oleh subjek S yang berusia 23 tahun. Sedangkan keputusan subjek $\mathrm{H}$ menjalankan profesinya sebagai pelaku seni peran salah satunya didasari oleh rasa khawatir dengan semakin terkikisnya kesenian dan kebudayaan lokal oleh kebudayaan asing. Sebagai konsekuensi utama atas profesinya tersebut, terlihat pada aspek ekonomi maupun aspek sosial berupa cemoohan dari lingkungan sekitar. Dengan adanya konsekuensi tersebut, namun keduanya tetap memilih untuk terus berkarya menekuni profesi tersebut dengan menjadi pelaku seni peran, menyiratkan adanya hal-hal yang dianggap sangat penting dan berharga dalam profesi tersebut serta memberikan nilai khusus bagi mereka berdua, sehingga layak untuk dijadikan tujuan hidup mereka. Dengan demikian peneliti memandang bahwa konsep mengenai kebermaknaan hidup dinilai tepat untuk digali lebih dalam dari dua orang yang berprofesi sebagai pelaku seni peran Sanggar Bandungmooi, yang hidup dengan konsekuensi cukup berat, yaitu dari aspek sosial dan ekonomi.

\section{Kebermaknaan Hidup}

Makna hidup adalah hal-hal yang dianggap sangat penting dan berharga serta memberikan nilai khusus bagi seseorang sehingga layak untuk dijadikan tujuan hidup. Menurut definisi di atas makna hidup berupa hal-hal yang ditemukan seseorang dalam hidup yang mempunyai nilai khusus bagi kehidupan individu, dengan adanya nilai khusus, maka makna hidup layak untuk dijadikan tujuan hidup bagi individu tersebut. Menurut Zaharudin dan Amaliyah (2005), jika individu berhasil menemukan makna hidupnya, maka individu tersebut akan merasa bahwa 
kehidupannya sangatlah berarti dan berharga, dan pada akhirnya akan menimbulkan penghayatan bahagia sebagai efek sampingnya.

Makna hidup menurut Steger (2011 seperti yang dikutip oleh Setyarini \& Atamimi, 2011) dapat didefinisikan dengan tiga sudut pandang. Pertama, purpose centered definitions, sudut pandang ini mempunyai landasan bahwa setiap manusia memiliki tujuan, makna hidup mengacu pada motivasi pengejaran individu terhadap tujuan hidupnya. Kedua, significance definitions, seseorang memperoleh makna hidup ketika memahami informasi atau pesan yang didapat dari hidupnya. Ketiga, multifaceted definitions, merupakan kombinasi dari dimensi afeksi, motivasi dan kognisi, yaitu bagaimana seseorang merasakan, memenuhi atau pencapaian dalam kehidupan.

Menurut Frankl (seperti yang dikutip oleh Bastaman, 2007) dalam kehidupan ini terdapat tiga kegiatan yang berpotensi mengandung nilai-nilai bagi seseorang untuk menemukan makna hidup, ketiga nilai ini adalah creative values, experiential values dan attitudinal values. Creative values adalah kegiatan berkarya/ menciptakan, bekerja atau kegiatan yang sifatnya memenuhi kewajiban dan tanggung jawab. Menekuni suatu pekerjaan, rasa tanggung jawab tinggi terhadap tugas serta berusaha mengerjakan dengan sebaik-baiknya merupakan contoh berkarya. Experiential values adalah nilai-nilai penghayatan akan keyakinan, penghayatan terhadap nilai-nilai kebenaran, kebajikan, keindahan, keimanan, keagamaan dan cinta kasih. Meyakini dan menghayati nilai-nilai positif dapat menjadikan seseorang berarti hidupnya. Contohnya, tidak sedikit orang-orang dapat menemukan arti hidup setelah menghayati nilai-nilai agama. Attitudinal values adalah nilai-nilai bersikap yaitu menerima dengan penuh ketabahan, kesabaran, dan keberanian dari segala bentuk penderitaan yang tidak mungkin dielakkan lagi, seperti sakit dan kematian.

Beberapa sifat khusus dari makna hidup yaitu: 1). Unik, yang berarti sifatnya pribadi atau subjektif, mengingat makna hidup setiap orang akan berbeda. 2). Spesifik dan nyata, yang berarti makna hidup haruslah bersumber dari peristiwa yang nyata atau benar-benar terjadi dalam kehidupan sebenarnya. 3). Memberikan pedoman dan arah, yang berarti tujuan manusia adalah untuk menemukan makna hidup, maka dari itu seakan-akan kita terpanggil untuk melaksanakan dan memenuhinya, serta kegiatan- kegiatan kita pun lebih mengarah kepada pemenuhan tersebut (Bastaman, 2007).

Menurut Bastaman (1996, seperti yang dikutip dalam Ritonga \& Listiari, 2006) terdapat enam komponen yang dapat menentukan keberhasilan perubahan sumber makna hidup dan penghayatan hidup yang tidak memiliki makna menjadi lebih bermakna, keenam komponen tersebut diantaranya: 1) Pemahaman diri, yaitu adanya kesadaran atas keadaan buruk yang terjadi dan adanya keinginan yang kuat untuk mengubah situasi buruk menjadi lebih baik. 2) Makna hidup, yaitu adanya pemahaman bahwa makna hidup memiliki nilai yang penting dan nilai tersebut berfungsi sebagai tujuan hidup yang harus dipenuhi serta menjadi pengarah atas segala kegiatannya. 3) Perubahan sikap, yaitu perubahan dari yang tidak tepat menjadi tepat dalam menyelesaikan permasalahan, kondisi hidup atau musibah yang tidak terelakkan. 4) Keterikatan diri, yaitu adanya keterikatan terhadap makna hidup yang ditemukan dan tujuan hidup yang ditetapkan. 5) Kegiatan yang terarah, 
artinya segala upaya yang dilakukan individu secara sadar dan sengaja merupakan pengembangan atas potensipotensi diri yang positif serta pemanfaatan relasi antar pribadi untuk menunjang tercapainya makna dan tujuan hidup. 6) Dukungan sosial, yaitu hadirnya seseorang atau sejumlah orang yang dapat dipercaya, selalu bersedia memberi bantuan demi menunjang seseorang menemukan hidup yang bermakna.

Komponen makna hidup sebenarnya tidak dikemukakan oleh Bastaman saja, ada beberapa tokoh yang juga mengemukakan komponen makna hidup, salah satunya adalah Steger (2006) yang menyatakan bahwa aspek makna hidup terdiri dari presence of meaning dan search of meaning. Presence of meaning, Aspek pertama ini menekankan pada sesuatu yang sifatnya subjektif atau individual terkait makna hidup yang dimiliki seseorang. Aspek ini menekankan sumber makna hidup dalam kehidupan seseorang. Artinya makna hidup yang ditemukan oleh seseorang haruslah diketahui awal mula kehadirannya. Search of meaning, Aspek yang kedua menekankan pada dorongan dan orientasi seseorang terhadap penemuan makna hidupnya. Pencarian makna hidup ini merupakan elemen yang terpenting dalam menemukan makna hidup.

Pencarian makna hidup dapat ditemukan saat manusia diberikan ujian oleh Allah Swt. Sesungguhnya setiap manusia akan diberikan ujian sesuai kadar kemampuannya, hal ini ditujukan untuk menaikan derajat manusia itu sendiri. Hal ini selaras dengan firman Allah Swt.: "Dan sungguh kami akan berikan cobaan kepadamu, dengan sedikit ketakutan, kelaparan, kekurangan harta, jiwa, dan buah-buahan. Dan beritakanlah berita gembira kepada orang-orang yang sabar.
Yaitu orang-orang yang apabila ditimpa musibah mereka mengucapkan innaa lillaahi wa innaa ilaihi raaji'uun. Mereka itulah yang mendapat keberkatan yang sempurna dan rahmat dari Tuhan mereka, dan mereka itulah orang-orang yang mendapatkan petunjuk" (QS. Al-Baqoroh: 155-157).

Ayat tersebut di atas diperkuat dengan hadis yang memiliki arti "Besarnya pahala sesuai dengan besarnya ujian dan cobaan, sesungguhnya Alloh bila menyayangi suatu kaum, Alloh akan menguji mereka, barang siapa bersabar maka baginya manfaat kesabarannya dan barang siapa murka maka baginya murka Alloh" (HR. Tirmidzi). Ujian hidup merupakan salah satu situasi bagi manusia dalam melakukan pencarian makna hidup. Dengan diberikannya ujian, manusia diharapkan mempunyai jiwa sabar dan senantiasa bersyukur atas apapun yang dihadapinya. Jiwa sabar dan syukur dapat membantu manusia dalam melakukan pencarian makna hidup, dengan begitu mempunyai jiwa sabar dan syukur akan memudahkan manusia mengubah penghayatan hidup yang tidak bermakna menjadi bermakna. Hidup dengan mengaplikasikan sabar dan syukur merupakan salah satu cara ibadah manusia terhadap tuhannya.

\section{Metode}

Metode penelitian menggunakan pendekatan kualitatif dengan jenis penelitian fenomenologi untuk menggali sebuah variabel penelitian yaitu kebermaknaan hidup. Langkah-langkah penelitian ini mengikuti pendapat yang dikemukakan Stevick, Colaizzi dan Keen (dalam Hasbiansyah, 2005; h. 171) yaitu: menetapkan fenomena, .menyusun daftar pertanyaan, pengumpulan data, analisis 
data, deskripsi esensi dan penyusunan laporan.

Subjek dalam penelitian ini adalah dua orang pelaku seni peran di Sanggar Bandungmooi. Seniman yang dimaksud adalah mereka yang tekun dalam menjalankan karirnya sehingga menghiraukan konsekuensi dalam bekerja dan aktif dalam menghasilkan karya. Karakteristik subjek pertama yaitu seorang laki-laki berinisial $S$ yang berusia 23 tahun, berprofesi sebagai pelaku seni peran sejak tahun 2010, dan banyak menghasilkan karya. Adapun karakteristik subjek kedua yaitu seorang laki-laki berinisial $\mathrm{H}$ yang berusia 50 tahun, berprofesi sebagai seniman sejak tahun 1980, serta banyak menghasilkan karya berupa naskah dan pegaleran.

Tabel 1

\section{Identitas Subjek}

\begin{tabular}{lcc}
\hline \multicolumn{1}{c}{ Subjek } & Subjek 1 & Subjek 2 \\
\hline Inisial & S.O.P & H \\
Usia & 24 tahun & 50 tahun \\
Suku & Sunda & Sunda \\
bangsa & & \\
Agama & Islam & Islam \\
Jenis & Laki-laki & Laki-laki \\
kelamin & & \\
Pendidikan & S-1 & S-1 \\
& (Jurusan & (Jurusan \\
& Teater, & Teater) \\
& sampai & \\
& semester & \\
& $5)$ & \\
Profesi & Pelaku & Pelaku seni \\
& seni & \\
Jabatan & Ketua & Penanggung \\
& sanggar & jawab \\
& & sanggar \\
\hline
\end{tabular}

Pengumpulan data dilakukan selama tiga bulan yaitu bulan Januari hingga Maret
2018. Teknik pengumpulan data menggunakan observasi dan wawancara yang mengungkap enam dimensi kebermaknaan hidup berdasarkan dimensi yang dikemukakan oleh Bastaman. Untuk memperkuat data hasil observasi dan wawancara dan observasi, penelitian ini juga menggunakan alat ukur dari Steger yaitu Meaning in Life Questionnaire (MLQ) yang mengukur dua aspek yaitu presence of meaning dan search of meaning. Alat ukur ini terdiri dari 10 pernyataan, dengan tujuh pilihan jawaban yang bergerak dari angka 1 (Sama Sekali Tidak Benar) sampai dengan angka 7 (Benar Sekali).

Untuk menjamin keabsahan data, dilakukan melalui trianggulasi teknik serta trianggulasi waktu. Trianggulasi teknik dilakukan dengan digunakannya beberapa teknik berbeda yaitu observasi, wawancara, kuesioner, dan dokumentasi. Sedangkan trianggulasi waktu dilakukan dengan cara melakukan wawancara dan observasi pada waktu yang berbeda yaitu pada tiga kali pertemuan untuk masing-masing subjek.

Langkah analisis data yang dilakukan yaitu: Pertama, mendeskripsikan fenomena yang dialami subjek dari data hasil wawancara ataupun observasi. Seluruh rekaman hasil wawancara ditranskipsikan dan disusun ke dalam tulisan. Kedua, peneliti memilih pertanyaan dan jawaban yang relevan dengan enam dimensi kebermaknaan hidup yaitu makna hidup, perubahan sikap, pemahaman diri, keterikatan diri, kegiatan yang terarah dan dukungan sosial. pada tahap ini peneliti bertugas untuk mengklasifikasikan pertanyaan dan jawaban ke dalam tematema tertentu. Ketiga, pada tahap ini dilakukan (a) textural description yaitu peneliti menuliskan dan mendeskripsikan apa yang dialami individu; (b) structural 
description yaitu penulis menuliskan bagaimana fenomena yang bersangkutan dialami oleh individu, dengan mempertimbangkan data riwayat hidup serta alat ukur MLQ.

\section{Hasil}

\section{Subjek Pertama}

Makna hidup. Sebagai pelaku seni peran $\mathrm{S}$ memiliki pandangan hidup ketika mengerjakan sesuatu dapat bermanfaat baik bagi orang lain maupun bagi diri sendiri, merasa nyaman dan $\mathrm{S}$ merasa senang mengerjakannya. Bermanfaat bagi orang lain yaitu ketika S sebagai ketua Sanggar Bandungmooi dapat berbagi ilmu yang ia miliki dengan ikhlas kepada anggota sanggarnya. Nyaman diartikan ketika mengerjakan sesuatu tanpa adanya tekanan dan sesuai dengan potensi yang dimilikinya. Merasa senang ketika sesuatu yang dikerjakan sesuai dengan harapan. Selain itu bermanfaat bagi diri sendiri diartikan ketika mengerjakan sesuatu, ia berhasil mendapatkan suatu keahlian baru.

"Hidup bagi saya, apa yang saya senangi dan apa yang saya bermanfaat bagi saya dan apa yang bermanfaat bagi orang lain, dan saya nyaman didalamnya, saya hidup disana." (KH.A1.01.S1.W1)

"Nyaman tuh, tidak tertekan, terus sesuai dengan kebisaan saya dilingkungan situh, apa sih..kan ini kesenian, lingkungannya teater, teater itu aku bisa, aku kan bisa..nah itu ku nyaman disitu. Aku bisa dan nyaman, kalo misalnya aku sekarang euhhh hidup dilingkungan, yang bikin mesin lingkungan nya tuh, kan ga nyaman..kan ga nyaman kan." (KH.A1.01.S1.W1)

$S$ telah menemukan makna hidupnya yaitu, dapat bermanfaat bagi orang lain, di samping itu merasa nyaman karena ia merasa kompeten dalam mengerjakan sesuatu. Bermanfaat bagi orang lain dan perasaan nyaman saling berkaitan, artinya ketika $\mathrm{S}$ merasa nyaman maka akan semakin besar pula kebermanfaatan dirinya bagi orang lain.

"Yaaa..balik lagi makna hidup urang, makna nya yaa untuk itu tadi, bermanfaat bagi orang lain.. beres." (KH.A1.02.S1.W1)

"Bermanfaat dan nyaman." (KH.A1.03.S1.W1)

Bagi S, makna hidupnya sudah cukup mewarnai tujuan-tujuan yang ditetapkan oleh dirinya. S dapat menyalurkan potensi maupun ilmu yang dimilikinya kepada anggota sanggar, melalui proses latihan untuk mengikuti perlombaan. Makna hidup bermanfaat dan nyaman yang dipegang $S$, dapat memengaruhi cara pandang terhadap proses berkesenian yang ia lakukan, serta hasil yang sudah didapatkan, artinya meski hasil yang didapatkan tidak sesuai dengan harapan, bagi $\mathrm{S}$ yang terpenting diri dan anggotanya telah melakukan yang terbaik untuk pementasan. Selain itu, makna hidup yang dipegang $\mathrm{S}$ dapat berfungsi sebagai motivasi bagi dirinya dalam berkegiatan dan berkarya.

"Yaa pengaruhlah, jadi contohnya, ayeuna urang bertujuan, ... urang punya ilmu, urang punya apa.. nah salurin ke temen temen, ... jadi selama euh manfaat hidup urang anu bieu, ngaruh ka barudak terus barudak bisa membuktikeun tah eta geus sesuai tu kitu keur urang teh". (KH.A1.04.S1.W1)

"Heem, yaa jadi motivasi urang terus menerus weh, terus bertindak, terus bertindak, jadi urang ga mau berhenti, terus aja." (KH.A1.05.S1.W1)

Pemahaman diri. Sebagai pelaku seni dirinya memiliki konsekuensi positif juga negatif. Konsekuensi positif diantaranya memiliki relasi sesama seniman, sehingga dapat menjadi sumber datangnya ilmu dan 
rejeki. Selain itu, kemampuan berbicara $\mathrm{S}$ meningkat. Mengingat posisinya sebagai ketua yang terbiasa mengatur anggota maupun sebuah pementasan, yang kemudian ia aplikasikan dalam kehidupan bermasyarakat. $\mathrm{S}$ juga merasakan manfaat bagi dirinya yaitu menjadi pribadi yang lebih kreatif, hal ini diperkuat oleh $\mathrm{S}$ yang berusaha berkarya untuk menghasilkan sesuatu yang baru dan tergolong unik, hasil karya $\mathrm{S}$ salah satunya berupa mengkonversi lagu metal dengan menggunakan alat musik ukulele. Konsekuensi positif yang dirasakan $\mathrm{S}$ turut berpengaruh terhadap makna hidupnya, dimana hasil karyanya tersebut dapat bermanfaat bagi orang lain.

Adapun beberapa konsekuensi negatif diantaranya: sering mendapatkan teguran dari masyarakat sekitar ketika melakukan kegiatan latihan; kesulitan mendapatkan pekerjaan disebabkan stereotype masyarakat yang memandang tidak baik; sering dipandang sebelah mata oleh saudara karena dianggap tidak bekerja; serta pada aspek ekonomi, berupa penghasilan yang didapat belum tetap karena masih tergantung ramai atau sepinya panggilan pentas.

"Nah, kalo keadaan urang sebagai seniman, positifnya hehehe urang sosial lebih kerasa gitu, ... lamun negatifna urang amun dikeseharian nya eta, ... selama ini memang seniman dipandang masyarakat gitu, nah itu negatifnya." (KH.A2.01.S1.W1)

"Udah sih eta, jadi urang sebagai pelaku seni yang urang dapatkan, jadi lebih kreatif, jadi lebih apa yah ...." (KH.A2.01.S1.W1)

"Itu sih, kalo dari saudara dipandang sebelah mata, soalna urang teu gawe, jadi urang teh diliatnya teu gawe, teu boga duit, so taukan hehehe." (KH.A2.01.S1.W1)
Adanya konsekuensi negatif tidak membuat $\mathrm{S}$ diam dan menerima begitu saja. Stereotype kurang baik terhadap dirinya membuat $\mathrm{S}$ tertantang untuk membuktikan eksistensinya sebagai dengan karya yang dihasilkan atau materi yang didapat dari hasil berkesenian. Selain itu S mengubah penampilan menjadi rapi dan berpakaian pantas. Adapun cara $\mathrm{S}$ menyikapi teguran masyarakat sekitar yaitu mengatur waktu jadwal latihan dengan cara menyesuaikan kegiatan masyarakat sekitar dengan jadwal latihan.

"Dulu tuh urangkan gondrong, sobeksobek, celana sobek, lutut sobek, kuleheu, kuceul, kumeul, dulu itu yaa, sekarang mah kan udah engga, udah sadar "oh kudu kieu yeuh, kudu rapih" seengganya rambut pendek gitulah dengan baju anu formallah tong soek teuing." (KH.A2.02.S1.W2)

"Emm menyikapinya gampang tinggal atur waktu waktuna henteu, emm liat waktu siang, ... berarti atur waktu, ya saya latihan berarti sorenya." (KH.A2.02.S1.W2)

Perubahan sikap. Pertama kali S menekuni dunia seni awalnya hanya ikutikutan pementasan di berbagai sanggar, sekarang $\mathrm{S}$ menjadi lebih teguh pendirian dengan mengikuti Sanggar Bandungmooi hingga dipercaya menjadi ketua. Pada awalnya $\mathrm{S}$ diatur oleh orang lain, maka saat ini $\mathrm{S}$ dapat mengatur dirinya sendiri bahkan dapat mengatur orang lain, yaitu anggotanya. Selain itu awalnya tujuan S hanya sekedar mencari kesenangan, tetapi saat ini menjadi lebih berkompeten karena lebih mendalami dunia teater. Dengan adanya stereotype masyarakat terhadap $\mathrm{S}$ yang dipandang urakan, $\mathrm{S}$ berusaha mengubah diri dengan cara memperbaiki penampilan menjadi lebih rapi dan memperbaiki tingkah lakunya. 
Selain itu pertama kali S merasakan senang dalam berkesenian, saat ini menjadi pribadi yang sabar karena turut menjadi pengurus. Tingkat kesenangan yang dirasakan berbeda karena awalnya merasakan kesenangan tetapi tidak memiliki tujuan, sedangkan saat ini rasa senangnya karena mendapatkan hasil dari apa yang dikerjakan.

"Ah beda, jadi kalau dulu tuh, masih bingung, ngapain nih aku, dulu tuh masih ikut-ikut, ah ini kesini ikut, ini kesini ikut, masih belum punya jati diri gitu, ... sekarang udah bisa terorganisir oleh sendiri keseniannya gitu, engga ikut lagi ke orang lain." (KH.A3.01.S1.W1)

"Engga sih dulu, kan dulu masih asikasikan doang ga mendalami." (KH.A3.01.S1.W1)

Keterikatan diri. $\mathrm{S}$ sangat terikat dengan makna hidup yang dipegangnya yaitu bermanfaat bagi orang lain dan nyaman dengan apa yang dikerjakan. Setiap kegiatan berkesenian yang dilakukan saat ini merupakan bentuk dari keinginannya untuk bermanfaat bagi orang lain dan untuk hidup nyaman. Termasuk ketika $\mathrm{S}$ berkegiatan membuat konten youtube, prinsip bermanfaat dan nyaman tersebut tetap ia pegang.

"Kalau sekarang sih, terikat pisan, urang kudu bermanfaat yeuh, lamun urang teu bermanfaat ke orang lain urang diem dirumah sekarang, ga berkesenian, soalna manfaat urang yaa itu kesenian, kalau saya ga terikat, saya pasti diem di rumah." (KH.A4.01.S1.W1)

"Kalau buat yang nyaman, yaa sama saya diem aja, misalnya kalau saya ga nyaman disini saya mending di rumah, urang masih terikat gitu sama kenyamanan itu kalu misal ga nyaman urang ga ada di sini." (KH.A4.01.S1.W1)
S masih terikat untuk mencapai tujuan yang telah ditetapkan. Seperti halnya, S masih memperjuangkan untuk menjadi seniman. Kriteria seniman ideal menurut $\mathrm{S}$ berupa eksistensi diri dan sanggarnya dengan karya-karya yang dihasilkan dan konsisten untuk menciptakan karya. Selain itu, $S$ juga masih memperjuangkan tujuannya untuk memiliki penghasilan yang tetap serta menjadi youtuber.

"Kalau ditanya seberapa terikat, masih terikat, soalnya tujuan hidupkan masih diperjuangkan, belum sampai tujuan saya sekarang, jadi masih diperjuangkan, misal tujuan saya mau jadi seniman, masih belum menjadi seniman banget, seniman itu masih perlu nikah meureun, masih perlu yang lain lainnya, itu masih belum, masih proses." (KH.A4.02.S1.W1)

"Ohh, penghasilan yang tetap eta, tujuan urang diluar seniman yaitu penghasilan yang tetap (ohh penghasilan yang tetap, tujuan saya diluar seniman punya penghasilan yang tetap)." (KH.A4.02.S1.W2)

Kegiatan yang terarah. $\mathbf{S}$ melakukan upaya-upaya demi menemukan makna hidupnya, yaitu dengan terus mengadakan kegiatan ataupun acara kesenian.

"Yaa itu tadi, membuat kegiatan, membuat acara, pokoknya engga membuat aku diem dirumah aja." (KH.A5.01.S1.W1)

$\mathrm{S}$ juga melakukan upaya dengan mencoba berbagai kemampuan untuk menemukan potensi dirinya, hal ini menyebabkan $\mathrm{S}$ dapat menentukan jurusan kuliah yang dianggap paling sesuai dengan potensinya. Terkait tujuan $\mathrm{S}$ untuk mempunyai pendapatan yang tetap, dirinya telah merencanakan memiliki industri kreatif sendiri, perencanaan $\mathrm{S}$ disertai dengan beberapa alternatif seperti, industri kreatif yang diinginkan $\mathrm{S}$ yaitu mempunyai pabrik gitar. 
"Iyaa, makanya urang coba dulu, tah potensi urang didieu, maka dari itu urang masuklah, sebelum masuk kuliah teh urang teh geus sadar gitu." (KH.A5.02.S1.W1)

"Saya pengen saya bikin pabrik gitar yang puguh, terus saya pengen bikin misal, bikin jam dari barang bekas atau apa gitu, sketboard urut, sapu urut." (KH.A5.02.S1.W2)

Terkait dengan upaya yang telah dilakukan S, baik untuk penemuan makna hidup atau untuk menemukan tujuan hidup, sangat sesuai dengan potensi yang dimilikinya. Karena $\mathrm{S}$ berprinsip sesuatu yang dilakukannya harus sesuai dengan potensi dirinya, hal ini tentu disebabkan makna hidupnya yaitu untuk hidup nyaman.

"Sesuai pisan, soalnya lamun urang henteu sesuai jeung potensi urang, urang teu bisa (sangat sesuai, soalnya ketika tidak sesuai, saya tidak bisa mengerjakannya)." (KH.A5.03.S1.W1)

Selain upaya yang dilakuakn sendiri, $\mathrm{S}$ mencoba memanfaatkan lingkungan sosial, dengan selalu mencoba memberdayakan tenaga di luar sanggar. Ketika situasi tidak memungkinkan untuk memanfaatkan lingkungan social, $\mathrm{S}$ terus berstrategi.

"Misalna urang dimusik, ngamusikan teaternya, misal urang ga ada yang bantu nih urang ngamusikan teater solusinya yaa saya mixing lagu, butuh gitar, gitarnya direkam, gitarnya perlu iringan drum, drumnya direkam jadi satu di mixing nah nanti pas pertunjukan teaternya tinggal di play." (KH.A5.04.S1.W2)

Dukungan Sosial. Lingkungan sekitar $S$ turut berperan penting dalam penemuan makna hidupnya, karena keinginannya untuk mempelajari ilmu seni teater diawali dengan dorongan dari luar yaitu lingkungan ekstrakurikuler dan seringnya $\mathrm{S}$ menonton pagelaran teater yang juga diperkuat dengan dorongan dalam diri S. Begitu pula dengan keputusan S untuk mempelajari seni musik yang diawali motivasi dari luar yaitu teman sebayanya. Setelah berprofesi menjadi pelaku seni peran, bagi S lingkungan yang berkontribusi dalam penemuan makna hidupnya yaitu guru dan temannya. Banyak hal yang didapatkan dari guru seperti ilmuilmu baru dan solusi baik permasalahan berkesenian atau permasalahan pribadinya. Peran paling penting guru adalah sebagai fasilitator dalam menjalankan profesinya. Adapun peran teman sanggar meliputi dukungan material berupa jasa dan uang. Selain itu peran teman terkait dengan keberadaan mereka sebagai objek kebermanfaatannya saat ini.

"Banyak, dapet ilmu, ilmunya banyak, ilmu teater, ilmu pemikirannya, ilmu euh.. jadi kalau urang lagi bingung "mang urang gimana mang" dapet solusi lebih ke temen share, dan lebih ke gurulah, dapet semuanya lah kesenian dari mang." (KH.A6.01.S1.W1)

"Teman di sanggar, mereka kan partner saya berkesenian." (KH.A6.01.S1.W2)

Peran orang tua untuk dirinya berupa izin atau restu untuk $S$ menjalankan profesinya. batasan bagi $S$ dalam bertingkah laku dan bertanggung jawab. Terkadang orang tua berperan memberikan inspirasi dalam berkarya. Adapun saudara dan tetangga $\mathrm{S}$ dipandang kurang peduli terhadap S dan profesinya.

"Mendukung gitu, jadi kalau aku mau ngapain silahkan, kalau aku mau ini silahkan, asal engga negatif. Gini, si bapa pernah bilang, " $k i$ jadi naon ayeuna, seniman, oke jadi seniman asal bertanggung jawab"." (KH.A6.02.S1.W1)

"kriteria negatif sama tanggung jawab tuh dikasih orang tua”. (KH.A6.02.S1.W2)

"Kalau teman responnya biasa saja, baiklah, kalau saudara, tetangga, kurang 
peduli sih, kurang respon.” (KH.A6.03.S1.W1)

\section{Subjek Kedua}

Makna hidup. $\mathrm{H}$ mempunyai pandangan bahwa hidup harus dipersiapkan dengan cara menentukan jalan sendiri yaitu mempertimbangkan agama dan ilmu. Hidup juga harus mempunyai manfaat, baik terhadap diri sendiri maupun orang lain dengan berbagi ilmu atau menyampaikan pesan baik melalui karya seninya, dan bermanfaat dengan tenaganya. $\mathrm{H}$ memandang hidup dengan selalu percaya terhadap penciptanya yaitu Allah Swt. melalui sikap optimis dan rasa bersyukur. $\mathrm{H}$ mempunyai prinsip untuk hidup sederhana tetapi dalam kesederhanaan tersebut, tetap menyempatkan untuk berbagi. Jadi sebagai pelaku seni peran dirinya tidak meminta dahulu kepada kesenian tapi memberi dulu terhadap kesenian. Dengan kata lain, ketika ia dapat menyuguhkan karya yang baik terhadap penonton, maka diri dan karyanya akan disukai banyak orang, hal ini berarti ketika hidup banyak memberi maka kita akan mendapatkan lebih dari pemberian itu.

"Yaa untuk yang bermanfaat, yaa salah satunya saya menyalurkan ilmu saya, berbagi kepada yang lain, ... juga memberi pencerahan kepada yang lain, misalkan jagalah kebersihan lewat bahasa kesenian saya, atau jagalah air ini. Kan bahasa kesenian mah bahasa simbol, yang selalu memberikan pencerahan tentang hidup, ..." (KH.A1.01.S2.W1)

"Saya berprinsip, siapa yang berbuat dia akan dapat, jadi berbuatlah dulu sebelum mendapatkan sesuatu ..." (KH.A1.01.S2.W1)

"Yaa sederhana saja hidup, tidak muluk-muluk hidup, memandang hidup itu jangan mulu-muluk. Sederhana saja, dengan kesederhanaan kita bisa hidup dan bisa berbagi." (KH.A1.01.S2.W1)

$\mathrm{H}$ telah menemukan makna hidupnya yaitu, sebagai pelaku seni dirinya dapat bermanfaat bagi orang lain. Hal ini disebabkan kesenian bukan sebatas hiburan, melainkan sebagai tuntunan hidup. Menurut $\mathrm{H}$ seni lahir hasil dari hubungan manusia dengan alam, sosial dan Tuhannya. Dengan begitu $\mathrm{H}$ dapat berdakwah dengan kesenian, artinya menyampaikan pesan Tuhan kepada masyarakat sesuai dengan tuntunan agama dan Alquran. $\mathrm{H}$ memandang seni teater merupakan cerminan kehidupan, maka nilai seni harus memberikan tuntunan yang baik kepada masyarakat agar bermanfaat dengan mengubah karakter seseorang menjadi lebih baik.

"Yaa bermanfaat bagi orang lain". (KH.A1.03.S2.W1)

"Iyaa kepenonton dan ke kita sebagai pelaku, ... karena itu untuk menyuarakan itu bagaimana orang supaya mau memelihara alam, bahwa alam itu jangan sampai dirusak, ..." (KH.A1.02.S2.W2)

Bagi H, makna hidupnya sudah cukup mewarnai tujuan-tujuan yang ditetapkan oleh dirinya. Salah satunya keinginan $\mathrm{H}$ untuk berkesenian bersama orang lain dimanifestasikan dengan sikap $\mathrm{H}$ yang terbuka terhadap siapapun yang akan menggunakan fasilitas sanggarnya serta terbuka berbagi ilmu. Lalu tujuan $\mathrm{H}$ untuk melestarikan kebudayaan lokal diwujudkan dengan kemampuan analisa untuk mengakulturasi budaya yang masuk dengan budaya lokal. Selain melestarikan budaya, $\mathrm{H}$ juga turut andil dalam membangun karakter anak didiknya agar muncul sikap mandiri dan cerdas dari segi pikiran, tubuh dan perasaan, hal ini $\mathrm{H}$ lakukan karena rasa khawatir $\mathrm{H}$ terhadap masa depan generasi bangsa. 
Makna hidup yang dipegang $\mathrm{H}$ dinilai cukup berpengaruh terhadap tindakan yang dilakukannya, seperti $\mathrm{H}$ membuka sanggar yang dikelolanya untuk dimanfaatkan masyarakat luar. Selain itu makna hidup $\mathrm{H}$ untuk bermanfaat bagi orang dinilai berpengaruh terhadap perilakunya untuk hidup sederhana. Ketika $\mathrm{H}$ mendapatkan rezeki lebih, dirinya cenderung lebih memilih untuk berbagi daripada dipergunakannya sendiri. Hidup sederhana dapat membuat dirinya lebih menikmati hidup.

"Saya tidak beorientasi kepada materi, silahkan orang yang ingin berlatih kepada saya, tidak perlu bayar, ... boleh minta inspirasi dari saya, ... kalau ilmu saya sudah nerap atau apa, turut main dengan saya dapat rejekinya dari ilmu yang sudah saya sampaikan ...." (KH.A1.04.S2.W1), (KH.A1.05.S2.W1)

"Yaa salah satunya khawatir pada budaya kita tergerus oleh budaya lain yaa, ke khawatiran itu juga timbul disaya, maka saya selalu emm menjaga budaya sendiri... makanya saya selalu menampilkan ciri khas kelokalannya ya ke indonesiaannya atau kebarat-baratannya, dan kecimahiannya." (KH.A1.04.S2.W1)

Pemahaman diri. Konsekuensi positif yang dirasakan $\mathrm{H}$ yaitu dapat memberikan hiburan, selain juga dapat berekspresi serta berbagi ilmu. Adapun konsekuensi negatif yaitu: merasa tidak dapat berbuat banyak dalam kehidupan ekonomi sehingga tidak dapat memberi materi lebih terhadap orang lain dan keluarga. Namun di sisi lain hal tersebut dipandang secara positif pula karena dengan tidak ambisi mengejar kekayaan, ia tidak menjadi pribadi yang sombong, tidak ketakutan kehilangan harta serta merasa nikmat menjalankan hidup dengan sederhana.
"Positifnya..yaa saya sebagai pemeran bisa memberi hiburan kepada orang lain, saya bisa berekspresi, menyalurkan fikiranfikiran saya. Negatifnya emm apaya.. yaa negatifnya mungkin ya itu tidak mengejar kekayaan lebih banyak, ..." (KH.A2.01.S2.W1)

"Iyaa positifnya, saya engga sombong, ... Nikmat saya mah pake motor butut ge, nyaman saya mah, dari pada motor anyar tapi kredit, diudag lising. ..." (KH.A2.01.S2.W3)

Ketidakmampuan secara ekonomi diimbangi dengan cara memaksimalkan pikiran dan tenaga yaitu dengan memperluas wawasan untuk dibagikan kepada orang lain. Sejak awal $\mathrm{H}$ telah mempersiapkan diri dan mental untuk menghadapi konsekuensi tersebut.

"Emm yaa saya menyiapkan fikiran saya dan memaksimalkan ilmu saya dan tenaga saya, karena saya tidak bisa berbuat banyak dengan harta saya, maka saya harus berbuat banyak dengan ilmu saya, jadi saya bisa menutupi yang tidak bisa saya maksimalkan itu." (KH.A2.02.S2.W1)

"Iyaa tau, emang dari dulu tau konsekuensinya, ... yaa tapi seiring dengan jalan yaa "lahaullawallakuataillabillah" mencoba kenapa tidak, karena saya yakin profesi saya akan memberikan penghargaan secara materil maupun moril." (KH.A2.02.S2.W2)

Perubahan sikap. Pertama kali $\mathrm{H}$ menjadi pelaku seni peran, dari yang tidak mengetahui apa-apa menjadi lebih mengetahui makna hidupnya. Awalnya berkesenian hanya untuk sekedar hiburan, akan tetapi selanjutnya bertujuan untuk hidup bermanfaat. Saat ini $\mathrm{H}$ lebih bersemangat jika dibandingkan pada saat awal dirinya menekuni profesi. Dahulu karya seni $\mathrm{H}$ tidak mempunyai nilai jual, berbeda dengan sekarang dimana karya 
seninya sudah memiliki harga material dan moral. Awal berprofesi dirinya hanya mengandalkan karya orang lain untuk dipentaskan, tetapi sekarang dirinya berproses dengan hasil karyanya sendiri. Perubahan dari dalam dirinya yang paling terasa adalah sifat keras dan kasar menjadi lebih bijak.

Setelah lebih mendalami profesinya, $\mathrm{H}$ merasa bahagia karena dapat berbagi ilmu yang dimiliki. Awalnya $\mathrm{H}$ merasakan penyesalan hingga mengalami frustrasi karena mempertimbangkan tuntutan dari orang terdekatnya. Namun, sekarang $\mathrm{H}$ sangat menikmati hidupnya karena dapat berinteraksi dengan berbagai generasi juga berinteraksi dengan alam dalam arti menjaga dan memelihara alam. Selain itu $\mathrm{H}$ juga senang karena dapat mengkampanyeukan penjagaan alam terhadap masyarakat melalui pesan seninya. $\mathrm{H}$ merasa bangga dan bahagia karena menjadi pribadi yang lebih bijaksana dan peka terhadap permasalahan sosial dan permasalahan alam.

"Yaa dulu ada bahagia, cuman kebahagiaannya hanya sebatas bahagia biasa gitu. ... dan itu itu membuat saya senang, ... ngobrol dengan berbagai generasi, ngobrol dengan alam." (KH.A3.02.S2.W1)

"Yaa saya merasa bahagia dan bangga, saya merasa bangga berada disini, mungkin kalau saya ada ditempat lain, saya bukan menjadi orang yang bijaksana atau mungkin bukan menjadi orang yang peka terhadap kondisi lingkungan, ..." (KH.A3.02.S2.W1)

“... karyanya dulu juga sangat beda, dulu mah yang menggunakan karya-karya orang lain nah sekarang mah karya-karya sendiri, mau goreng mau alus mencoba karya sendiri daripada membesarkan karya orang lain kan gitu lebih baik karya sendiri, nanti orang yang akan menilai." (KH.A3.01.S2.W2)

Keterikatan diri. $\mathrm{H}$ sangat terikat dengan makna hidupnya saat ini, terbukti dengan terus menekuni profesinya tanpa ada rasa menyesal karena ia tidak memprioritaskan jabatan atau harta. $\mathrm{H}$ merasa terikat dengan cita-cita agama untuk membangun peradaban yang lebih baik.

“... perubahan ke arah yang lebih baik, membangun peradaban yang lebih baik, lewat agamanya, lewat keseniannya, lewat hal apapun, sebenarnya itukan citacita agama, cuman cita-cita agama itu mungkin tertanam pada diri saya." (KH.A4.01.S2.W2)

$\mathrm{H}$ juga merasa terikat dengan tujuan hidupnya yaitu masih memperjuangkan cita-cita untuk bermanfaat bagi orang lain melalui berbagi materi dengan porsi lebih banyak. Terkait pencapaian tujuan hidup, $\mathrm{H}$ mengimbangi dengan terus merancang strategi, selain juga selalu menyadarkan diri sendiri ketika lalai untuk mencapai tujuan hidupnya.

"Yaa terus, saya selalu mengingatkan diri saya, emm menyadarkan diri saya sendiri, karena orang lain tidak tau tujuan hidup sayakan, jadi saya harus menyadarkan diri sendiri, misalkan terlupakan, bangkitkan lagi, ..." (KH.A4.02.S2.W1)

Kegiatan yang terarah. $\mathrm{H}$ melakukan upaya-upaya demi menemukan makna hidupnya yaitu dengan terus berkarya dalam bidang kesenian. Ia juga tetap memberikan ilmu yang dimiliki, demi terrealisasikannya makna hidup yang ia harapkan.

"Upaya mah banyak, dari tadi yang dilakukan itu, memberikan ilmu dan saya henteu cicing gitu, bergerak, hidup manusia itu dengan mau bergerak, bergerak dan 
bergerak, dibidang kesenian ataupun dibidang apapun." (KH.A5.01.S2.W1)

Tujuan $\mathrm{H}$ untuk menghidupkan kembali seni longser diimbangi upaya melakukan penelitian mengenai seni longser dan terus mengadakan pelatihanpelatihan longser. Selain itu kekhawatiran $\mathrm{H}$ terhadap masa depan generasi penerus diimbangi dengan upaya melakukan pelatihan dengan tujuan mencerdaskan anak didiknya melalui pengolahan rasa, raga dan pikiran, yang pada tahap selanjutnya konsep pelatihan tersebut ingin dituangkan ke dalam bentuk buku agar dapat dibaca masyarakat umum.

"Yaa saya meyakinkan diri saya, misalkan saya pengen suatu saat nanti ada sekolah misalkan semacam sekolah longser tau tempat kursus longser nah sayakan melakukan uji coba eksperimen, melakukan emm pelatihan-pelatihan, nanti itu hasil coba itu akan menjadi sebuah bentuk. ..." (KH.A5.02.S2.W1)

Upaya-upaya yang dilakukan $\mathrm{H}$ sangat sesuai dengan potensi yang dimilikinya, karena $\mathrm{H}$ tidak mencari hal-hal yang dianggapnya tidak bisa dikerjakannya. Salah satu kesesuaian upaya yang telah dilakukan dengan potensi yang dimilikinya adalah $\mathrm{H}$ mampu memilih porsi yang tepat untuk orang lain, sesuai dengan potensi mereka.

"Sesuai dengan potensi saya memang, da kalau tidak sesuai saya tidak bisa berbuat sesuatu, jadi potensi saya memang emmm emm jadi gini saya tidak mencaricari hal yang tidak bisa saya bisa, jadi saya harus melakukan hal yang bisa, ..." (KH.A5.03.S2.W2)

Selain upaya yang telah dilakukan sendiri untuk menemukan makna hidup atau mencapai tujuan hidup, $\mathrm{H}$ juga mencoba memanfaatkan lingkungan social dengan cara meminta bantuan teman yang ahli di bidang ilmu pengetahuan lain.

"Makanya saya jika ada yang tidak sesuai saya meminta bantuan pada yang lain. Kita hidup itu tidak sendiri, semua akan kesuksesan saya nanti atau kesuksesan siapapun itu juga didukung oleh berbagai pihak, ...". (KH.A5.04.S2.W1)

Dukungan sosial. $\mathrm{H}$ merasakan memperoleh dukungan yang besar dari lingkungan social antara lain berasal dari istri dan keluarga berupa dukungan emosional dan spiritual. Sedangkan dari pihak lain meliputi materi atau dukungan instrumental dan dukungan informasional berupa ilmu dan pengalaman baru yang didapatnya. Selain peran dari dukungan sosial, $\mathrm{H}$ merasakan pula peran dari cobaancobaan hidup dalam penemuan makna hidupnya, dengan cara mengambil sisi positif dari apa yang terjadi, mempasrahkan diri dan menjadikan cobaan yang diterimanya sebagai pembelajaran hidup. Cobaan hidup yang pernah didapatkan $\mathrm{H}$ berupa teguran dari Tuhan, dari orang lain berupa cibiran, serta dari dirinya sendiri berupa kemalasan. Semua itu dijadikannya sebagai motivasi untuk melanjutkan hidup sehingga dapat berperan bagi dirinya menemukan makna hidup.

"Yaa sangat besar sekali yaa, emm misalkan istri emm mendukung, memahami, keluarga yang lain juga memahami, yang lain juga misal membantu saya melakukan pekerjaan saya, ... penyakit jadi teguran, kecelakaan jadi teguran, tapi semuanya menjadi penguat untuk memaknai hidup." (KH.A6.01.S2.W2), (KH.A6.02.S2.W2)

"Yaa cobaan ada, cobaan paling banyak yaa dari tuhan yang maha esa ada dari orang lain berupa cibiran atau apa, kan itu semua jadi pelajaran atau apa, dari berbagai hal gitu yaaa, ada juga cobaan dari diri sendiri yaa, misal cobaan saya 
malas itu juga jadi cobaaan, ...." (KH.A6.01.S2.W2)

\section{Diskusi}

\section{Subjek Pertama}

Berdasarkan data hasil observasi dan wawancara yang dilakukan kepada subjek S, maka dapat diperoleh gambaran bagaimana kebermaknaan hidup pada seorang pelaku seni.

Dilihat dari latar belakang keluarga $\mathrm{S}$ merupakan seorang laki-laki berusia 23 tahun. S adalah anak pertama dari dua bersaudara, $\mathrm{S}$ memiliki adik yang sudah meninggal ketika berusia di bawah lima tahun. Hubungan ibu dengan ayahnya harmonis, Karena pada setiap ada permasalahanpun semuanya bisa mereka atasi dengan baik. Sosok ibu digambarkan oleh S sebagai sosok yang baik dan aktif di lingkungan sosialnya, seorang ibu yang penyabar, tegas, juga cerewet ketika menghadapi anaknya. S menceritakan bahwa sosok ayah tidak berbeda jauh dengan ibu, yang membedakan hanya ibunya dirasa lebih cerewet dibandingkan ayahnya. Dalam hal mendidik ibu S lebih berperan dibandingkan dengan ayahnya.

Riwayat pendidikan $S$ yaitu pernah berkuliah di ISBI. S tidak melanjutkan kuliahnya, dan sudah berhenti berkuliah ketika semester lima, dikarenakan dirinya tidak mempunyai biaya untuk meneruskan kuliahnya. S menceritakan dengan memasuki ISBI, $\mathrm{S}$ merasa dirinya sudah menentukan pilihan yang tepat karena apa yang diajarkan di bangku perkuliahan dapat S praktikkan pada kehidupannya sekarang, mengingat dirinya kini berprofesi sebagai pelaku seni peran.

Ketika S mengendalikan emosi, ia memilih untuk diam dan menjauh dari keramaian. Ketika ada yang membuat kesalahan terhadap dirinya $\mathrm{S}$ lebih memilih melupakan kesalahan orang tersebut dari pada memaafkannya. $\mathrm{S}$ adalah pribadi yang mempunyai rasa empati yang tinggi, hal ini didukung dengan pertanyaan $\mathrm{S}$ yang mengatakan bahwa dirinya mudah merasa sedih jika menemukan peristiwa haru. Ketika mendapatkan cobaan dalam hidupnya, S lebih memilih untuk menyelesaikan masalahnya.

$\mathrm{S}$ mempunyai impian agar dirinya dapat menjadi seniman yang terkenal. Hal yang paling membanggakan dalam hidup $S$ yaitu ketika dirinya menjadi sutradara dan memenangkan sebuah perlombaan. Motivasi $\mathrm{S}$ dalam berkarya akan meningkat ketika banyak orang yang membantunya. Orang yang paling berpengaruh dalam kehidupan karir $\mathrm{S}$ adalah gurunya, yang berperan sebagai fasilitatornya. $\mathrm{S}$ memiliki hobi bermain gitar, di waktu lain $S$ juga seringkali membuat cerita pendek, bermain alat musik dan kesenian lainnya.

Terkait kehidupan relasi, hubungan dirinya dengan orang tua sangatlah baik. Selain itu hubungan $\mathrm{S}$ dengan saudaranya dinilai berjarak, hal ini dikarenakan $\mathrm{S}$ jarang sekali bertemu dengan saudaranya, meskipun begitu $\mathrm{S}$ tetap menyatakan hubungannya dengan saudara tetap baik jika bertemu. $\mathrm{S}$ mengatakan hubungan dengan temannya tergantung bagaimana teman $\mathrm{S}$ merespon dirinya. Hubungan $\mathrm{S}$ dengan pasangannya dinilai baik, Karena pada setiap ada permasalahanpun semuanya bisa mereka atasi dengan baik.

Aspek pertama adalah makna hidup, Menurut Bastaman (1996, seperti yang dikutip dalam Ritonga \& Listiari, 2006) adanya pemahaman bahwa makna hidup memiliki nilai yang penting dan nilai tersebut berfungsi sebagai tujuan hidup yang harus dipenuhi serta menjadi pengarah atas segala kegiatannya. Makna hidup yang $\mathrm{S}$ pegang adalah dapat bermanfaat bagi 
orang lain dan menjalankan kehidupannya dengan nyaman. Makna hidup yang nyaman berpengaruh terhadap keinginan $S$ untuk menjadi pelaku seni peran, karena $S$ memiliki potensi dalam bidang kesenian, lalu diperkuat oleh $\mathrm{S}$ yang sempat menuntut ilmu dalam bidang seni hingga menambah potensi berkesenian dalam dirinya. Sedangkan makna hidup $\mathrm{S}$ untuk bermanfaat bagi orang lain berpengaruh ketika ia mengikuti perlombaan orientasinya bukan menang tapi untuk menyuguhkan pementasan yang baik, maka dari itu $S$ merasa puas ketika dirinya sudah memberikan ilmu yang dimiliki terhadap juniornya, sudah mengarahkan anggotanya dengan baik, hingga anggotanya dapat menampilkan suatu pementasan yang baik. Makna hidup S yaitu dapat bermanfaat bagi orang lain dan merasa nyaman dalam menjalankan hidup menjadi motivasi $\mathrm{S}$ dalam melakukan kegiatan. Selain itu makna hidup $\mathrm{S}$ berpengaruh ketika ia menjalani profesinya sebagai pelaku seni peran. Artinya bermanfaat bagi orang lain, perasaan tidak tertekan dan sesuai dengan potensi membuat $\mathrm{S}$ tidak berhenti dalam berkarya.

Aspek kedua yaitu pemahaman diri, menurut Bastaman (1996, seperti yang dikutip dalam Ritonga \& Listiari, 2006) Maksud dari pemahaman diri adalah adanya kesadaran atas keadaan buruk yang terjadi dan adanya keinginan yang kuat untuk merubah situasi buruk menjadi lebih baik. Dalam menjalankan profesinya sebagai pelaku seni peran, $\mathrm{S}$ sering mendapatkan teguran dari lingkungan sekitar ketika melaksanakan kegiatan latihan, karena dalam melaksanakan kegiatan latihan dapat menghasilkan suara yang gaduh. Adanya teguran dari masyarakat sekitar membuat $\mathrm{S}$ ingin sekali melakukan perubahan, agar tidak lagi mendapatkan teguran. $\mathrm{S}$ menyikapi teguran dari masyarakat sekitar dengan cara mengatur jadwal agar sesuai antara jadwal latihan dengan kegiatan masyarakat.

Setelah menjadi pelaku seni peran $S$ menduga akan kesulitan bilamana mencari pekerjaan, hal ini disebabkan stereotype masyarakat terhadap pelaku seni yang dipandang tidak baik, maka dari itu $\mathrm{S}$ memiliki keinginan untuk mengubah stereotype masyarakat terhadap pelaku seni, dan perubahan itu dimulai dengan cara mengubah dirinya terlebih dahulu. $\mathrm{S}$ menyikapi stereotype masyarakat terhadap dirinya dengan cara mengubah penampilan dari yang sebelumnya berpenampilan urakan (berambut gondrong, terbiasa menggunakan pakaian sobek-sobek dan tidak merawat diri) menjadi rapi dan berpakaian pantas. Salah satu konsekuensi negatif menjadi pelaku seni peran yang $S$ rasakan yaitu terletak pada aspek ekonomi, maka dari itu sering kali $\mathrm{S}$ dipandang sebelah mata oleh saudaranya, karena $\mathrm{S}$ dianggap tidak bekerja. Maka dari itu $\mathrm{S}$ memiliki keinginan mengubah situasi tersebut dengan cara terus berusaha untuk membuktikan eksistensinya sebagai pelaku seni peran melalui karya yang dihasilkan atau materi yang didapat dari hasil berkesenian.

Aspek ketiga yaitu perubahan sikap, menurut Bastaman (1996, seperti yang dikutip dalam Ritonga \& Listiari, 2006) Maksud dari perubahan sikap adalah dari yang tidak tepat menjadi tepat dalam menyelesaikan permasalahan,kondisi hidup atau musibah yang tidak terelakan. Pertama kali S menekuni dunia seni awalnya hanya ikut-ikut pementasan di berbagai sanggar, saat ini $\mathrm{S}$ lebih teguh pendirian dengan mengikuti Sanggar Bandungmooi, hingga dipercaya menjadi ketua pada sanggar tersebut. Hal ini berpengaruh terhadap 
kehidupan $\mathrm{S}$ dalam menjalankan profesinya sebagai pelaku seni peran, yang awalnya $S$ diatur oleh orang lain, kali ini $\mathrm{S}$ dapat mengatur dirinya sendiri bahkan dapat mengatur orang lain, yaitu anggotanya, dan berpengaruh terhadap perasaan $\mathrm{S}$ yang awalnya menekuni profesi tersebut merasakan kesenangan tanpa memiliki tujuan, akan tetapi saat ini rasa senangnya berbeda, karena mendapatkan hasil dari apa yang dikerjakan. Salah satu perubahan yang dirasakannya yaitu ketika pertama kali menjadi pelaku seni peran dengan adanya stereotype masyarakat terhadap $\mathrm{S}$ sebagai pelaku seni peran yang dipandang urakan, $\mathrm{S}$ berusaha mengubah diri dengan cara memperbaiki penampilan menjadi lebih rapi dan memperbaiki tingkah lakunya.

Aspek keempat adalah keterikatan diri, menurut Bastaman (1996, seperti yang dikutip dalam Ritonga \& Listiari, 2006) Maksudnya keterikatan diri adalah adanya keterikatan terhadap makna hidup yang ditemukan dan tujuan hidup yang ditetapkan. S sangat terikat dengan makan hidup yang dipegangnya yaitu dapat bermanfaat bagi orang lain dan merasa nyaman dalam menjalankan hidup, karena setiap kegiatan berkesenian yang dilakukan saat ini merupakan bentuk dari keinginannya untuk bermanfaat bagi orang lain dan keinginan untuk nyaman dalam menjalankan hidup. Selain itu $\mathrm{S}$ juga masih terikat dengan tujuan hidup yang telah ditetapkannya seperti $\mathrm{S}$ masih terus membuat karya, membuat acara kesenian, dan terus belajar demi tercapainya tujuan untuk menjadi seniman. Selain itu S masih memperjuangkan tujuannya untuk memiliki penghasilan yang tetap dan $\mathrm{S}$ masih memperjuangkan tujuannya untuk menjadi youtuber dengan terus membuat kontenkonten baru.
Aspek kelima yaitu kegiatan yang terarah, menurut Bastaman (1996, seperti yang dikutip dalam Ritonga \& Listiari, 2006) Artinya segala upaya yang dilakukan individu secara sadar dan sengaja merupakan pengembangan atas potensipotensi diri yang positif serta pemanfaatan relasi antar pribadi untuk menunjang tercapainya makna dan tujuan hidup. Terkait dengan upaya yang telah dilakukan $\mathrm{S}$, baik untuk penemuan makna hidup atau untuk menemukan tujuan hidup, sangat sesuai dengan potensi yang dimilikinya, karena $\mathrm{S}$ berprinsip sesuatu yang dilakukannya harus sesuai dengan potensi dirinya, hal ini tentu disebabkan makna hidupnya yaitu untuk hidup nyaman. Dalam melakukan upaya-upaya tersebut, $\mathrm{S}$ mencoba memanfaatkan lingkungan sosial yaitu siswa/siswi yang dididiknya pada ekstrakurikuler teater di sebuah Sekolah SMA di Cimahi.

Aspek keenam yaitu dukungan sosial, menurut Bastaman (1996, seperti yang dikutip dalam Ritonga \& Listiari, 2006) Hadirnya seseorang/sejumlah orang yang dapat dipercaya, selalu bersedia memberi bantuan demi menunjang seseorang menemukan hidup yang bermakna. Dalam menemukan makna hidup terdapat peran dari lingkungan sosial bagi $\mathrm{S}$ seperti, gurunya yang mempunyai peran sebagai fasilitator bagi dirinya. Selain itu terdapat juga peran teman bagi $\mathrm{S}$ dalam menemukan makna hidupnya, dukungan dari teman yaitu dukungan material berupa barang kebutuhan pentas dan uang. Selain itu teman $\mathrm{S}$ berperan dalam menemukan makna hidup karena mereka adalah objek kebermanfaatannya. Selain guru dan teman terdapat juga dukungan orang tua berupa izin atau restu untuk $\mathrm{S}$ dalam menjalankan profesinya sebagai pelaku seni peran. 
Terkadang orang tuanya memberi dukungan berupa inspirasi dalam berkarya.

\section{Subjek Kedua}

$\mathrm{H}$ adalah seorang laki-laki yang berusia 50 tahun. Ia berstatus sebagai seorang suami dengan dua orang anak. Sedangkan posisi $\mathrm{H}$ di keluarga sebagai anak terakhir dari empat bersaudara. $\mathrm{H}$ menceritakan bahwa dirinya memiliki 2 adik lagi tetapi berbeda ibu, hal ini dikarenakan ayahnya telah bercerai dengan ibunya. Sosok ibu digambarkan sebagai sosok yang senang bersilaturahim dan loyal di lingkungan sosialnya, serta tegas dalam mendidik anakanaknya. Meskipun begitu ibunya tetap membebaskan anaknya menentukan jalan hidupnya sendiri. $\mathrm{H}$ menceritakan bahwa dirinya tidak begitu banyak mengenal ayahnya, karena ayah dan ibunya telah bercerai sejak $\mathrm{H}$ berusia 2 tahun. Meskipun begitu $\mathrm{H}$ senantiasa bersilaturahmi dengan ayahnya.

$\mathrm{H}$ pernah berkuliah di ISBI. Dia merasa sudah menentukan pilihan yang benar dengan berkuliah di ISBI karena apa yang diajarkan di bangku perkuliahan dapat $\mathrm{H}$ praktikkan pada kehidupannya sekarang, mengingat dirinya kini berprofesi sebagai pelaku seni peran. Ditambah dengan $\mathrm{H}$ adalah mahasiswa yang berprestasi ketika itu.

Dahulu H sangat sulit untuk mengendalikan emosi marahnya, tetapi berbeda dengan sekarang, dia menilai dirinya lebih bisa mengendalikan emosi marahnya. Ketika ada orang yang membuat kesalahan, $\mathrm{H}$ lebih memilih memaafkan orang yang pernah membuat kesalahan terhadapnya. $\mathrm{H}$ mudah merasa sedih ketika menyaksikan peristiwa yang mengharukan. Menurut $\mathrm{H}$ ketika mendapatkan cobaan hidup $\mathrm{S}$ lebih memilih untuk memperbaiki dari pada membuat dirinya terpuruk.
Tujuan terbesar $\mathrm{H}$ adalah dapat hidup selamat di dunia dan akhirat. Motivasi dirinya dalam berkarya dapat meningkat ketika dirinya mendapatkan cibiran dari orang lain. Tujuan karir $\mathrm{H}$ adalah dapat bermanfaat bagi orang lain, maka dari itu $\mathrm{H}$ mendefinisikan kesuksesan karir bukan berdasarkan materi melainkan besar manfaat subjek terhadap orang lain. Menurut $\mathrm{H}$ orang yang paling berperan dalam karirnya yaitu teman/partner dirinya berkesenian. Saat ini H gemar mengoleksi batu akik. Di waktu luangnya, $\mathrm{H}$ senang menghabiskan waktunya dengan mengurus batu akiknya. Selain mengurus batu akik $\mathrm{H}$ juga senantiasa membuat karya berupa naskah drama.

Dalam kehidupan relasinya, hubungan $\mathrm{H}$ dengan orang tuanya sangatlah baik terutama dengan ibunya, hal ini dikarenakan ia masih sering berinteraksi dengan ibunya. Tetapi $\mathrm{H}$ mengungkapkan bahwa dirinya tidak begitu mengenal banyak sosok ayahnya. Selain itu hubungan $\mathrm{H}$ dengan kakanya dinilai berjarak, hal ini dikarenakan $\mathrm{H}$ jarang sekali bertemu dengan kakaknya, meskipun begitu $\mathrm{S}$ tetap menyatakan hubungannya dengan kakanya tetap baik jika bertemu. Hubungan $\mathrm{H}$ dengan istrinya dinilai baik, dengan tidak pernah adanya masalah yang besar.

Aspek pertama adalah makna hidup, Menurut Bastaman (1996, seperti yang dikutip dalam Ritonga \& Listiari, 2006) adanya pemahaman bahwa makna hidup memiliki nilai yang penting dan nilai tersebut berfungsi sebagai tujuan hidup yang harus dipenuhi serta menjadi pengarah atas segala kegiatannya. Makna hidup yang dipegang $\mathrm{H}$ yaitu sebagai pelaku seni dirinya dapat bermanfaat bagi orang lain. Salah satu hal yang mendasari makna hidup yang dipegangnya adalah prinsip $\mathrm{H}$ mengenai seni bukan hanya hiburan 
melainkan dapat juga menjadi tuntunan hidup baik bagi penonton maupun bagi pemainnya. Oleh karena itu $\mathrm{H}$ senantiasa menyampaikan pesan-pesan religi melalui keseniannya. $\mathrm{H}$ berperan dalam membangun karakter anak didiknya agar tumbuh sikap mandiri dan cerdas dari segi pikiran, rasa dan tubuhnya, hal ini $\mathrm{H}$ lakukan karena rasa khawatir $\mathrm{H}$ terhadap masa depan generasi penerus. Keinginan $\mathrm{H}$ agar dapat berkesenian dengan orang banyak diiringi dengan sikap $\mathrm{H}$ yang terbuka bahkan membuka sanggar yang dikelolanya untuk dapat dimanfaatkan oleh masyarakat luar.

Makna hidup yang dipegang $\mathrm{H}$ berpengaruh terhadap perilakunya menjadi lebih sederhana. Sikap $\mathrm{H}$ ketika mendapatkan rezeki lebih, ia cenderung memilih untuk berbagi daripada dipergunakan untuk dirinya sendiri. Dengan kata lain $\mathrm{H}$ tidak ingin menyimpan harta, melainkan lebih memilih untuk berbagi harta.

Aspek kedua yaitu pemahaman diri, menurut Bastaman (1996, seperti yang dikutip dalam Ritonga \& Listiari, 2006) Maksud dari pemahaman diri adalah adanya kesadaran atas keadaan buruk yang terjadi dan adanya keinginan yang kuat untuk merubah situasi buruk menjadi lebih baik. Setelah menjadi pelaku seni peran $\mathrm{H}$ tidak dapat berbuat banyak dalam kehidupan ekonominya. Hal tersebut mengakibatkan dirinya tidak dapat memberi materi lebih terhadap keluarga dan orang lain. Meskipun begitu $\mathrm{H}$ memiliki rasa kepercayaan bahwa profesi yang digelutinya akan memberi penghargaan materil maupun moril terhadap dirinya. Ketidakmampuan $\mathrm{H}$ dalam aspek ekonomi diimbangi dengan cara memaksimalkan pikiran dan tenaganya. Cara $\mathrm{H}$ memaksimalkan pikiran dengan memperluas wawasan agar lebih banyak berbagi dengan ilmu.
Aspek ketiga yaitu perubahan sikap, menurut Bastaman (1996, seperti yang dikutip dalam Ritonga \& Listiari, 2006) Maksud dari perubahan sikap adalah dari yang tidak tepat menjadi tepat dalam menyelesaikan permasalahan,kondisi hidup atau musibah yang tidak terelakan. Awal dirinya berkesenian hanya untuk sekedar hiburan saja, akan tetapi setelah $\mathrm{H}$ memfokuskan diri dalam berkesenian, $\mathrm{H}$ mempunyai tujuan untuk hidup bermanfaat. Saat ini $\mathrm{H}$ lebih bersemangat jika dibandingkan pada saat awal dirinya menekuni profesi pelaku seni peran. Perubahan dari dalam dirinya yang paling terasa ketika awal memutuskan menjadi pelaku seni, $\mathrm{H}$ memiliki sifat keras dan kasar, namun setelah lebih mendalami profesinya $\mathrm{H}$ menjadi pribadi yang lebih bijak. Dengan menjadi pelaku seni peran $\mathrm{H}$ merasa bangga dan bahagia karena menjadi pribadi yang lebih bijaksana dan peka terhadap permasalahan sosial dan permasalahan alam.

Aspek keempat adalah keterikatan diri, menurut Bastaman (1996, seperti yang dikutip dalam Ritonga \& Listiari, 2006) Maksudnya keterikatan diri adalah adanya keterikatan terhadap makna hidup yang ditemukan dan tujuan hidup yang ditetapkan. $\mathrm{H}$ sangat terikat dengan makna hidup yang dipegangnya yaitu dapat bermanfaat bagi orang lain. Hal ini terbukti dengan $\mathrm{H}$ terus menekuni profesinya tanpa ada rasa menyesal karena kehidupan $\mathrm{H}$ berbeda dengan individu pada umumnya dengan tidak mengejar apa yang pada umumnya orang lain kejar (tidak berorientasi terhadap harta atau jabatan). Selain itu $\mathrm{H}$ juga masih terikat dengan tujuan hidup yang telah ditetapkannya seperti masih memperjuangkan cita-cita untuk bermanfaat bagi orang lain melalui berbagi materi dengan porsi lebih banyak. Untuk mencapai tujuan 
hidupnya, $\mathrm{H}$ mengimbangi dengan terus merancang strategi demi tercapainya tujuan. Selain itu $\mathrm{H}$ juga selalu menyadarkan dirinya sendiri ketika dirinya lalai untuk mencapai tujuan hidupnya.

Aspek kelima yaitu kegiatan yang terarah, menurut Bastaman (1996, seperti yang dikutip dalam Ritonga \& Listiari, 2006) Artinya segala upaya yang dilakukan individu secara sadar dan sengaja merupakan pengembangan atas potensipotensi diri yang positif serta pemanfaatan relasi antar pribadi untuk menunjang tercapainya makna dan tujuan hidup. Terkait upaya $\mathrm{H}$ dalam menemukan makna hidup dan untuk mencapai tujuan hidup, tidak semua upaya yang dilakukan $\mathrm{H}$ sesuai dengan potensi yang dimilikinya, hal ini dikarenakan terdapat beberapa upaya $\mathrm{H}$ yang membutuhkan tenaga ahli lain bahkan di bidang ilmu pengetahuan lain. Dalam melakukan upaya-upaya tersebut, $\mathrm{H}$ mencoba memanfaatkan lingkungan sosial. Ketika pelatihan yang dirancangnya membutuhkan tenaga lain di bidang ilmu pengetahuan lain, $\mathrm{H}$ tidak pernah sungkan meminta bantuan teman yang ahli di bidang ilmu pengetahuan lain.

Aspek yang keenam yaitu dukungan sosial, menurut Bastaman (1996, seperti yang dikutip dalam Ritonga \& Listiari, 2006) Hadirnya seseorang/sejumlah orang yang dapat dipercaya, selalu bersedia memberi bantuan demi menunjang seseorang menemukan hidup yang bermakna. Dukungan yang didapatkan $\mathrm{H}$ antara lain berasal dari istri dan keluarganya berupa dukungan emosional dan spiritual. Selain itu $\mathrm{H}$ juga mendapatkan dukungan dari pihak lain berupa instrumental dan dukungan informasional. Selain adanya dukungan sosial terhadap penemuan makna hidup $\mathrm{H}$, terdapat pula dukungan dari cobaan hidup dalam menemukan makna hidupnya. Cobaan hidup seperti penyakit yang diderita, teguran dari Tuhan Yang Maha Esa, cibiran dari orang lain dan kemalasan dalam diri, dijadikan pelajaran oleh $\mathrm{H}$ dengan mengambil sisi positif dari apa yang terjadi.

Setelah S menjalani profesi sebagai pelaku seni peran dirinya dapat memainkan beberapa tugas perkembangan dewasa awal yaitu, peran suami istri dengan memiliki pasangan, peran orang tua dengan membiasakan diri mengatur anggotanya, mencari nafkah dengan konsisten dalam menjalani profesinya, pengembangan sikap yang tergambar dari mengubah penampilan dari yang sebelumnya $\mathrm{S}$ berpenampilan urakan; berambut gondrong, terbiasa menggunakan pakaian sobek-sobek, tidak merawat diri menjadi rapi dan berpakaian pantas. $\mathrm{S}$ juga sudah mulai membentuk bidang pekerjaan yang akan ditangani sebagai karirnya dengan komitmen, konsisten dalam pemilihan karir. Sedangkan H dari beberapa tugas perkembangan usia dewasa madya, yang paling terlihat pada diri $\mathrm{H}$ yaitu agama dan kepercayaan. H selalu menyangkut pautkan kehidupan dan profesi dengan sisi agama.

\section{Simpulan}

$\mathrm{S}$ dan $\mathrm{H}$ merupakan pelaku seni peran yang memiliki makna hidup untuk bermanfaat bagi orang lain. Selain itu, S memiliki makna hidup lainnya yaitu nyaman dalam menjalankan hidup. Ketika menjalankan profesinya sebagai pelaku seni peran keduanya tetap memegang teguh makna hidupnya. $\mathrm{S}$ dan $\mathrm{H}$ memiliki konsekuensi negatif dalam menjalankan profesinya, namun mereka berupaya mengatasi konsekuensi tersebut. Setelah menjadi pelaku seni peran, terdapat perubahan sikap baik pada diri $\mathrm{S}$ maupun pada diri $\mathrm{H}$ dalam menyikapi kondisi hidup.

Selain terikat dengan makna hidup, $\mathrm{S}$ dan $\mathrm{H}$ merupakan individu yang terikat dengan tujuan hidup yang telah ditetapkannya. Upaya yang dilakukan keduanya dalam menjalani 
profesi dinilai sesuai dengan potensi yang dimilikinya. $\mathrm{S}$ dan $\mathrm{H}$ menemukan makna hidupnya baik dari hasil upaya sendiri maupun hasil dari memanfaatkan dan memperoleh dukungan dari lingkungan sosialnya.

\section{Saran}

Beberapa saran yang dapat diajukan bagi pelaku seni peran yakni untuk mempertahankan makna hidup yang dipegangnya sehingga mereka dapat berperilaku berdasarkan makna hidup tersebut. Selain itu, peneliti selanjutnya diharapkan dapat menggali variabel-variabel lainnya yang dapat digambarkan dari para pelaku seni peran, misalnya gratitude, kepuasan hidup dan sebagainya. Penelitian selanjutnya diharapkan dapat memperluas subjek penelitian untuk menggali lebih banyak data.

\section{Referensi}

Agustini, M. (2016). Self efficacy dan makna hidup pada penderita penyakit koroner. eJournal Psikologi, 4.

Ashaqi, S. (2015). Kumpulan Hadis tentang cobaan hidup. Diunduh pada November 2017 dari http://talimulquranalasror.blogspot.co.id/2 015/03/kumpulan-hadits-tentang-cobaanhidup.html

Bastaman, H. D. (2007). Logoterapi: Psikologi untuk menemukan makna hidup. Jakarta: Raja Grafindo Persada.

Burhanudin, N. (2011). Al-Qur'an. Bandung: Media Fitrah Rabbani.

Charlys, \& Kurniati, N. M. T. (2007). Makna hidup pada biarawan. Jurnal Psikologi, 1, 33-39.

Hasbiansyah, O. (2005). Pengantar praktik penelitian dalam Ilmu Sosial dan Komunikasi. Pendekatan Fenomenologi, 9 , 163-180.

Hasporo, L. P. (2015). Kontruksi identitas aktor di era globalisasi. Jurnal Sosiologi, 2, 213 235.

Purnamasari, dkk. (2013). Pengaruh kebutuhan dan globalisasi terhadap minat remaja pada kesenian tradisional di Desa Patoman Kabupaten Pringsewu. Jurnal.
Ritonga, B., \& Listiari, E. (2006). Kebermaknaan hidup mahasiswa Sekolah Tinggi Theologia Nazarene Indonesia ditinjau dari tingkat religiusitasnya. Jurnal Psikologi, 2, 1-7.

Santosa, dkk. Ed. (2008). Seni teater. Jakarta: Direktorat Pembinaan Sekolah Menengah Kejuruan.

Setyarini, R., \& Atamini, N. (2011). Self esteem dan makna hidup pada pensiunan pegawai negeri sipil (PNS). Jurnal Psikologi, 38, 176-184.

Steger, M. F. dkk. (2006). The meaning in life questionnaire. Journal of Counseling Psychology, 53.

Sugiyono. (2015). Metode penelitian manajemen. Bandung: Alfabeta.

Sumanto. (2006). Kajian psikologis kebermaknaan hidup. Buletin Psikologi, 14(2), 115-136.

Suneki, S. (2012). Dampak globalisasi terhadap eksistensi budaya daerah. Jurnal Ilmiah CIVIS, 2(1), 307-321.

Zaharudin, \& Amaliyah, R. (2005). Efektivitas muhasabah dalam proses pencapaian makna hidup pada santri kelas XI jurusan IPS Madrasah Aliyah pondok pesantren Al-Ittifaqiyah Idralaya Kabupaten Ogan Hilir. Jurnal Psikologi, 1-8. 
MAKNA HIDUP DIBALIK SENI TRADISIONAL: STUDI FENOMENOLOGI KEBERMAKNAAN HIDUP SENIMAN SUNDA 